\title{
The Integration of Self-directed Learning and Employee Competency in the 21st Century
}

\author{
Sanhakot Vithayaporn* \\ Faculty of Business and Technology, Stamford International University, Thailand
}

Siew Siew Yong

Faculty of Business, Curtin University, Malaysia

\section{Elena Gregoria Chai}

Faculty of Social Sciences \& Humanities, Universiti Malaysia Sarawak, Malaysia

*Corresponding author: sanhakot@,hotmail.com

\begin{abstract}
The purpose of this paper is to examine the promotion of self-directed learning (SDL), a concept that can potentially increase employee competency in organisations. We present SDL as a pivotal 21 st century skills that transforms traditional practices into competencies crucial for the success of an employee at the workplace. The paper utilised case studies, document analysis, and a systematic literature review to synthesise existing resources. A systematic review of 50 peerreviewed articles published in English-language Scopus indexed journals indicate the significance of promoting SDL in the 21 st century workplace for employee competency development. The findings further highlight the practices that need to be integrated for SDL promotion in the workplace to enhance employee competency. Specifically, communication of a shared vision and knowledge among employees is essential to promote SDL. The literature suggests that SDL must be supported by employers and implemented in human resource development (HRD). The practical implications of this for Asian businesses is to introduce and inculcate SDL in organisational culture through a reward system and a conducive working environment. Overall, in recent years, researchers have recognised the critical role of SDL in the workplace in enhancing employee competencies by transferring the learning responsibility to employees.
\end{abstract}

Keywords: Self-directed learning, Employee competency, 21st century skills, Asia context, Labour workforce, Human resource development 


\section{Introduction}

The 21 st century workforce requires candidates with high academic qualifications and multiple critical thinking skills, particularly in the Asian context. The labour market in Asia has been characterised by a high degree of job migration both within and outside the country. The International Labour Organisation (ILO) (2014) reported that Asia and the Pacific accounted for 56.2 per cent of the world's labour force at around 1.7 billion people (ILO, 2014). The Philippines, in particular, provided the largest number of labour immigrants at 1.4 million in 2014 (ILO, 2014). After two years of significant growth, the labour migration situation from Asian countries stabilised in 2014. As in many other areas of the world, the Asia-Pacific region places a premium on expertise and growth in accordance with national competency requirements. These requirements serve as a guideline for the variety of skills and expertise needed by an industry (ILO, 2014).

Emerging markets in the Asian region continue to grow from an economic perspective. The labour force plays a vital role in driving the region's competitive advantage. It is estimated that 70 per cent of global growth over the next few years will come from emerging markets, and most of which are in Asia (Ernst \& Young, 2013). The International Monetary Fund (IMF) forecasted that the total gross domestic product (GDP) of emerging markets could overtake that of developed economies as early as 2014 (IMF, 2010). Skill development is thus crucial for the Asian region in response to this significant change. In particular, building employee competency through lifelong learning must be addressed to ensure that skillful employees exist in the labour force.

The first principle of the European Pillar of Social Rights states that "everyone has the right to quality the inclusive education, training, life-long learning to maintain, and acquire skills that enable them to participate fully in society and successfully manage transitions in the labour market". Additionally, it states that "everyone has the right to timely and tailor-made assistance to improve employment or self-employment prospects". This includes the right to receive support for job searches, training, and requalification" (European Commission, 2018, p. 11-12).

Similarly, Thailand's 20-Year National Strategy Plan's for Developing, and Strengthening Human Capital section is determined to ensure that Thais of all age groups attain adequate development in all dimensions, so they are equipped with the skills and qualities required for the 21st century; the achievement of lifelong learning is an indicator of such development (National Strategy, 2018). The competency approach can be a tool to support the human capital aspect of the national plan via policies to improve quality of life through education, learning, and training. Moreover, the workforce today demands an increase in competency, particularly in 21 st century skills, which also aligns with the vision of Thailand 4.0 as an industrialised country (Office of the National Economic and Social Development Board, 2017, p. 6).

As a result, developing individual competency in Asian countries is critical to increase employees' opportunities to work abroad with competencies that meet employers' requirements, given that a lack of such competencies is the main barrier for new graduates to enter the work field. Indeed, the gap between graduates' job skills and the skills needed in the workplace must not be overlooked. Ultimately, the possession of 21 st century skills is necessary for employability (OECD, 2013), which calls for individual competencies to align with such skills (McGunagle \& Zizka, 2020). 
First, it must be clarified that while 'competencies' and 'abilities' might denote similar meanings, they are in fact distinct, albeit interrelated. Sanghi (2007) explained from the learning and development perspective that the term ability has been understood as either being able to do something or possessing a special talent for completing a task. On the other hand, the term competencies refer to an individual's expertise and experience in life, gained through his/her learning process (Brockmann et al, 2009). The clear meaning of competencies thus lies within the learning process, especially self-learning, and can be measured through the quality of task completion and objective achievement (Mannayong \& Haerul, 2020). Therefore, people can and must enhance their competencies through experience, education, and training.

The differences, similarities, and usage of the terms 'competency' and 'competence' have been debated from several perspectives. It can be summarised that competence is skill-based, which involves something that can be learned and trained. Competency, meanwhile, is related to behaviour-based skills and describes an individual's characteristics and personality (Brockmann et al., 2009). This paper focuses exclusively on competency in the employee context.

In order to enhance competency in individuals, there is a need for them to self-initiate. According to Lindeman (1926), the concept of self-directedness originally referred to adults' natural need to act in a self-directed pathway, which was emphasised since the 1920s. Later, self-directed learning (SDL) was widely developed for adult learning, both from educational and practical perspectives. This paper aims to posit SDL as a tool to enhance the competencies of employees with latest skills. The term of employee is defined as those contributing to a nation's economic system, namely the agriculture sector, manufacturing sector, and service sector (Anderson, 2006). To develop employees' competencies, the employees from those three sectors must develop different skills. Indeed, 21 st century skills are most likely aligned with service sectorbased employees, who fall into the categories of management, corporate, and government employees. Consequently, this paper focuses on the context of employees in the service sector.

This paper aims to present the proposed practices and models to promote SDL for employee competency in 21 st century skills. However, limited studies in the literature have integrated the concepts of SDL and employee competency. Existing studies have revealed the importance of employee competency through training and development programmes provided by employers for organisational effectiveness, especially in the service industry (Anderson, 2006; Edward, 2010; Ha, 2015). Most studies have, in fact, established that training and development by organisations influences employee competency (Pereira et al., 2020; Marsick et al, 2009). This indicates that organisational management and policies impact employees' competency but has neglected the role of employees' self-development through SDL. Thus, SDL has been widely studied as a determinant of teachers' abilities in the educational context, yet the integration of SDL to promote employee competencies in 21 st century skills has not been studied extensively in the Asian context, which represents a gap in the study of SDL as a key driver of employee competency. Therefore, this study aims to investigate the key role of SDL in enhancing employee competencies that fulfil 21 st century skills requirements, given that SDL explains how employees, especially fresh graduates, can independently learn skills, prepare themselves, and apply them in their workplaces. 


\section{Literature Review}

\section{Definition of 'employee' from the Asian perspective}

With reference to the existing literature from Asia context, formal definitions of fulltime and part-time employees are minimal. In general, an employee is conceptualised as someone who has agreed by contract to perform specified services for another (i.e., the employer) in exchange for money, with a significant legal boundary that often determines the individual's rights to compensation. This definition was taken to represent full-time employees in countries with a service-based economy that recruit persons with undergraduate degrees. The definition of 'employee' in the existing literature from Asia is presented in Table 1.

Table 1: Diverse Definitions of Employee in the Asian Context

\begin{tabular}{|c|c|c|c|}
\hline Author/Year & Region/Country & Context & Description \\
\hline $\begin{array}{c}\text { Bentley and } \\
\text { Kyvik (2012) }\end{array}$ & Asia & General & $\begin{array}{l}\text { An individual employed by an employer } \\
\text { according to an agreement and performs } \\
\text { duties according to a job description is } \\
\text { called a full-time employee. The average } \\
\text { full-time working hours per week are } \\
49.7 \text { in Asia. }\end{array}$ \\
\hline $\begin{array}{l}\text { Felipe et al. } \\
\text { (2020) }\end{array}$ & Philippines & $\begin{array}{l}\text { Agriculture, } \\
\text { Services }\end{array}$ & $\begin{array}{l}\text { An employee is defined as a person } \\
\text { performing a task/duty according to a } \\
\text { paid contract. It can be divided into full- } \\
\text { and part-time, where full-time } \\
\text { employees work at least } 40 \text { hours a } \\
\text { week while part-time employees work } \\
\text { less, according to their respective } \\
\text { agreements. }\end{array}$ \\
\hline $\begin{array}{l}\text { Manpower } \\
\text { Research and } \\
\text { Statistics } \\
\text { Department } \\
\quad(2020)\end{array}$ & Singapore & General & $\begin{array}{l}\text { An employee is an individual employed } \\
\text { by an employer to perform a duty. } \\
\text { There are two types of employees, full- } \\
\text { and part-time. Full-time workers in } \\
\text { Singapore worked an average of } 45 \\
\text { hours per week in } 2019 \text {; part-time } \\
\text { workers worked an average of } 21 \text { hours } \\
\text { weekly in the same year. }\end{array}$ \\
\hline $\begin{array}{l}\text { Uijtdewilligen } \\
\text { et al. (2017) }\end{array}$ & Singapore & General & $\begin{array}{l}\text { The agreement between an employer and } \\
\text { employee to hire the latter to perform a } \\
\text { task/duty. All individuals under a contract } \\
\text { of service with an employer are covered. }\end{array}$ \\
\hline \multirow[t]{2}{*}{$\begin{array}{l}\text { Fagan et al. } \\
\text { (2014) }\end{array}$} & $\begin{array}{l}\text { Indonesia, } \\
\text { Thailand }\end{array}$ & General & $\begin{array}{l}\text { An employee is known as a contract } \\
\text { worker who is employed under a } \\
\text { definite term employment agreement. } \\
\text { The types of work for employees under } \\
\text { contract can be divided into full- and } \\
\text { part-time. }\end{array}$ \\
\hline & & & $\begin{array}{l}\text { In Indonesia, part-time workers are } \\
\text { those who work less than } 35 \text { hours } \\
\text { weekly, while full-time workers work } \\
45 \text { hours a week at minimum. }\end{array}$ \\
\hline
\end{tabular}




\begin{tabular}{|c|c|c|c|}
\hline $\begin{array}{l}\text { Widyahening } \\
\text { et al. (2014) }\end{array}$ & Indonesia & Service & $\begin{array}{l}\text { In Thailand, a full-time employee } \\
\text { works at least } 45 \text { hours per week while } \\
\text { part-time hours are defined as } 30 \text { or } \\
\text { less. Full-time employees are entitled } \\
\text { for benefits provided by the employer, } \\
\text { such as health insurance coverage, } \\
\text { training, and development. Part-time } \\
\text { employees have less access to training, } \\
\text { promotions, and union membership. } \\
\text { Indonesian primary care physicians } \\
\text { who practice more than } 30 \text { hours per } \\
\text { week are defined as full-time } \\
\text { practitioners. }\end{array}$ \\
\hline $\begin{array}{l}\text { Tan and Tan } \\
\text { (2002) }\end{array}$ & Singapore & Service & $\begin{array}{l}\text { Singapore has another type of } \\
\text { employee called temporary employees. } \\
\text { A temporary worker is defined as one } \\
\text { who is engaged by an employment } \\
\text { agency to work on different } \\
\text { assignments for different client } \\
\text { companies. Temporary workers work } \\
\text { on assignments for a finite period and } \\
\text { then move on to other client companies. } \\
\text { These temporary assignments can last } \\
\text { from a few hours to a few months or } \\
\text { even a year, and they can be full- or } \\
\text { part-time. }\end{array}$ \\
\hline
\end{tabular}

\section{Definition and importance of competency}

The root of the word 'competency' is derived from the original Latin word 'competentia', which can be interpreted as "being authorised to judge, respectively, a person who has the right to speak" (Skorkova, 2016). This meaning refers to human rights in a society where people can voice what they think and feel (Skorkova, 2016). Later, the definition of competency was modified to be more closely related to job performance. For instance, Klemp (1980) conceptualised competency as "an underlying characteristic of a person which results in effective and/or superior performance on the job" (p. 21). Competency is also known as a cluster of related knowledge, skills, and attitudes that reflects a major portion of one's job (a role or responsibility), that correlates with performance on the job, that can be measured with well-accepted standards, and that can be improved with training and development (Parry, 1996, p. 50). In the $21^{\text {st }}$ century, Northoue (2004) defined employee competency as a skill that is measurable or observable by the pre-conceived attitudes, traits, or personalities of a person.

According to Kunzmann (2006), competencies are defined as the integrated application of knowledge, skills, values, experiences, contacts, external knowledge resources, and tools to solve a problem or perform an activity. Additionally, Potnuru and Sahoo (2016) stated that competencies are considered the aspects of skills, knowledge, and abilities that are visible to measure. Furthermore, Lee (2010) defined employee competencies as those characteristics or traits acquired by employees, such as knowledge, skills, abilities, and personality, that differentiate them from average 
performers. Next, Sarboini (2016) defined employee competence as a skill and knowledge-based ability supported by work attitude and its application in performing tasks pertaining to specified job requirements. Most recently, Mannayong and Haerul (2020) associated employee competence with employees' ability, knowledge, insight, and attitude used as a guide in carrying out work responsibilities. Notably, Pinyosinwat and Preudhikulpradab (2018) stated that the concept of competencies is dependent on challenges occurring by chance at each level in the organisation. With regard to the self, the leading challenges for an individual employee are to prepare oneself for management and leadership roles as well as to improve personal effectiveness and performance.

From the authors' point of view, employee competency can be conceptualised as the knowledge and skills that reflect an employee's capability to carry out assigned tasks successfully and achieve results in assessments, objectives, and knowledge. Companies expect employees who have full knowledge to reflect their competency by performing work in an effective manner with minimal instructions from top management. Therefore, competency is positively related to company requirements and performance. It is necessary to continually achieve superior efficiency through specific competencies that are required for different contexts.

\section{Competencies and skills required for the $21^{\text {st }}$ century}

Skills describe how employees apply the knowledge they obtain from SDL in the workplace to exhibit excellent performance. The essence of $21^{\text {st }}$ century skills is to create individuals who are able to apply their knowledge beyond traditional skills in a particular context. To stand out in the competitive business world, human capital represents a key factor in the achievement of organisational effectiveness, goals, and performance; hence, a $21^{\text {st }}$ century skillset, with the right employee competency, plays an important role in supporting organisational performance (van Laar et al., 2020). According to the World Economic Forum, "today's job candidates must be able to collaborate, communicate, and solve problems", which are skills developed mainly through social and emotional learning. Consequently, in addition to traditional skills, employers demand these social and emotional proficiencies as the latter equip employees to succeed in the evolving digital economy (Jaques, 2017).

Joynes et al. (2019) compiled a summary of the academic and practical perspectives of the skills, competencies, and attributes that comprise $21^{\text {st }}$ century skills. As per the World Economic Forum (2009), this summary can be consolidated into three key dimensions encompassing sixteen skills with primary professional attributes, as shown in Figure 1.

The first dimension is foundational literacies, which covers the fundamental skills wherein "literacy in the 21 st century means more than basic reading, writing, mathematics, and computing skills, but social skills to adapt themselves to a changing environment and communicate with people wisely" (World Economic Forum, 2009). The second dimension is competencies, commonly known as the 4Cs (Critical thinking, Creativity, Communication, and Collaboration), which refers to "the Framework for 21 st Century Learning" proposed by the US-based Partnership for 21 st Century Learning. The first skill in particular, critical thinking, is needed for problem-solving, as it is used to approach complex challenges in today's changing world. The third 
dimension is character qualities, which indicates the necessary skills, chiefly social and cultural awareness, for employees to adjust to the challenging environment (World Economic Forum, 2009).

Figure 1: 21 ${ }^{\text {st }}$ Century Skills Breakdown

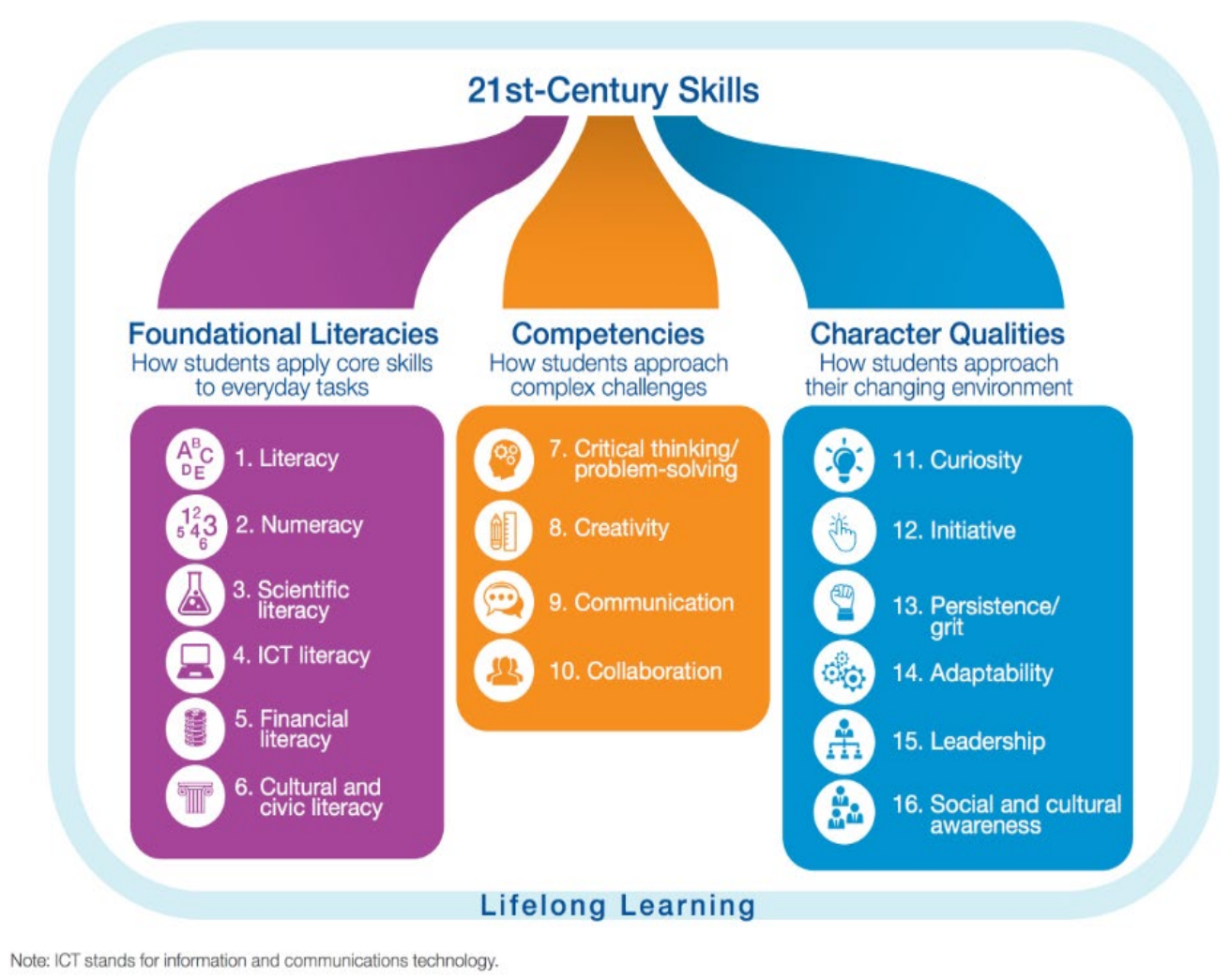

Source: World Economic Forum (2009)

These 21st century skills have been identified as critical success factors for individuals to secure and sustain career progress as an employee in the workplace. Hence, employers and organisations want their employees to develop skills from the 4Cs, which include critical thinking and problem solving, effective communication, collaboration and team building, and creativity and innovation (Jaques, 2017). The 4Cs model is presented in Figure 2.

The 4Cs model is based on the assertion that 21 st century challenges demand a broad set of skills surrounding an individual's capabilities in core subject mastery, social and cross-cultural skills, language proficiency, and an understanding of the economic and political forces that affect societies (McGunagle \& Zizka, 2020). Drawing on this analysis, each of the $4 \mathrm{C}$ skills is described below:

- Communication involves the capability to express thoughts clearly and persuasively using both verbal and non-verbal methods. Communication skills are also embedded in ICT literacy, information systems, and digital media access. These skills are the key competencies valued in both the workplace and in social life (Spies \& Xu, 2018).

- Collaboration is believed to be crucial in the future workplace, and all 
employees are expected to engage in highly networked collaboration, even when separated by distance or physical location. Moreover, employees need to be more comfortable with collaborating under distant conditions, as these types of interactions are encouraged in the workplace (Spies \& Xu, 2018).

- Critical thinking includes accessing, analysing, and synthesising information; it is the fundamental basis for student development. When in school, learning should involve activities that allow students to practice the use of critical thinking to solve problems. Interestingly, critical thinking skills can be taught, practiced, and mastered (McDonald, 2017).

- Creativity is defined as the capacity to generate new ideas and solutions. It involves breaking new ground, invoking fresh ways of thinking, posing unfamiliar questions, and arriving at unexpected answers (Scott, 2015). In every workplace, it is expected that employees have a creative mindset that entails the capability to contribute to the organisation.

Figure 2: The 4Cs model

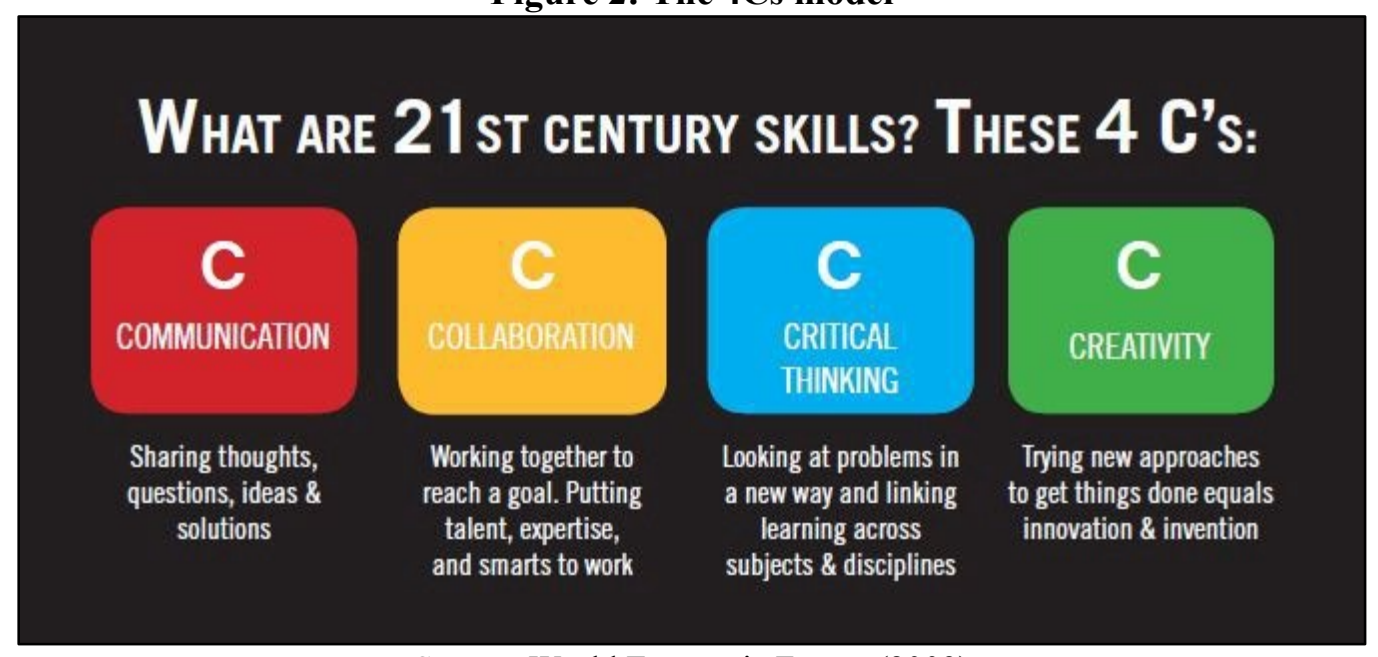

Source: World Economic Forum (2009)

Additionally, a range of core skills overlap and complement the $4 \mathrm{C}$ dimensions, including ICT literacy, social and cultural skills, and global citizenship. Likewise, innovation and invention are increasingly seen as required skills for professional and personal achievement, especially considering global competition and human competency demands. To comply with the labour market requirement, human resource development should investigate the skills that comply with the 21 st century. The acquisition of the skills and expertise required for each age group, role, and level of workers must be continuous to lay a solid basis for organisational efficiency. This can be done by introducing lifelong learning principles for all age levels in the workplace, with comprehensive and innovative knowledge and skills essential to the job market. Hence, organisations must introduce SDL practices in the workplace to enhance employee competency. This can be done by developing the 4Cs, i.e., communication, collaboration, critical thinking, and creativity, which are vital skills for an employee. The integration of SDL with the promotion of employee competency is discussed in the next section. 


\section{Self-directed learning (SDL) to enhance employee competency}

This section examines the practical aspects of SDL that enhance employee competencies in 21 st century skills required to be effective in the workplace. SDL is defined as a "process in which individuals take the initiative, without the help of others" in planning, carrying out, and evaluating their own learning experiences (Knowles, 1975). In principle, SDL is a primarily informal process that takes place outside the classroom beyond formal and non-formal education. Education also needs SDL to achieve learning objectives. The factor that qualifies learning as 'self-directed' is who makes decisions about the content, methods, resources, and evaluation of learning; in this case, it is the learner themselves. Individuals take responsibility for their learning process by determining their needs, setting goals, identifying resources, implementing a plan to meet their goals, and evaluating the outcomes (Knowles, 1975). The idea of self-directedness in learning emerged from andragogy, according to which adult learners are independently capable of elaborating on their learning goals, gaining significant experience with learning resources, applying situation sensitivity based on their experiences, and being motivated to learn through internal factors instead of external ones (Knowles, 1975).

Nonetheless, despite substantial literature on the influence of the learning organisation, organisational performance, and employee performance on SDL in the workplace (Marsick et al., 2014). Few studies have examined the interdependencies between SDL and employee competency or the specific practices that promote SDL in organisations for the development of individual employees (Cho \& Kwon, 2005).

For employees to remain knowledgeable, HRD and leaders are responsible for efforts to build learning infrastructures that effectively utilise both formal and informal learning (Ellinger, 2004). However, the global demand for economic competitiveness has made its increasingly challenging for organisations to facilitate the holistic growth of employees' knowledge and competency (Raveendran et al., 2021). Moreover, the trend of HRD has been affected by the Covid-19 pandemic since early 2020. Remote work has increased to secure employees from infection; thus, reinventing employee experience is essential for HRD to connect remote employees and ensure their performance levels. Also, HRD needs to alleviate concerns and resolve doubts from employees who are worried about job security, selection criteria, and the competencies they are evaluated on.

Not surprisingly, the concept of SDL has become a significant key to adult learning in the workplace, and SDL approaches have emerged as organisational effectiveness responses to the complex demands of the changing nature of work (Waitoller \& Artiles, 2013). By implementing SDL, employees can efficiently improve their competencies as well as their effectiveness through cost-effective strategies. The practice of SDL has thus been recognised as an important element in workplace learning research and practice, especially in cases where learning aims to develop employees' competencies. SDL is ultimately an assumption of employee competency enhancement that can be initiated by employees daily. It is an effective informal learning behaviour of employees who take the initiative to learn to develop skills and competencies for themselves.

Indeed, the most common practice of learning in the workplace emerges informally through self-directed behaviour (Yeo, 2008). As Ellinger (2004) argued, learning from 
typical workplace activities (e.g., learning from mistakes, interactions, self-managed observation, and training others) constitutes SDL because employees adopt the responsibility of individuals and groups when speaking about their learning. Therefore, individual self-directed action seems to be the key to enabling both continuous competence development and creativity (Boyer et al., 2013).

Globalisation has been described as the movement of business, industries, and professional activities into the global marketplace. Indeed, developing countries in Asia like Thailand, Myanmar, and Cambodia are competing at the regional and global level. In line with the World Trade Organisation (WTO) and the Asean Free Trade Area (AFTA). To meet global competitive demands, domestic industries must initiate productivity through employee competency. In this regard, SDL is the key driver of employee competency in Asian countries. Workplace learning is the process employees undergo to perform their duties. It includes the mindset, skills, and knowledge needed for their work. The learning mindset should be voluntary, not compulsory, to encourage learner autonomy. That is employees learn because they know the value of knowledge and the importance of acquiring 21 st century skills. They do not wait for organisational training programmes but rather initiate the SDL mindset in learning to evaluate and develop themselves.

\section{Methodology}

This paper posits SDL as a tool that enhances employee competency for $21^{\text {st }}$ century skills. The systematic literature review method was applied to probe into existing academic articles on SDL and employee competency. The benefit of a systematic literature review is that it provides transparent protocols by which researchers search for and assess a field of study relevant to a specific research topic; as such, it has been widely used in the social sciences as well as the business and management field (Deng, 2012; Macpherson \& Holt, 2007). The systematic literature review method in this paper is defined by the criteria shown in Figure 3 to set the search boundaries as protocols of the search strategy.

First, the search covered the 20-year period from 2000 to 2020 , as the focus of this paper is on $21^{\text {st }}$ century skills. It was conducted in several databases, including Web of Science, Scopus, PubMed, Google Scholar, and EBSCO, to avoid missing out relevant articles. Second, the authors sourced peer-reviewed articles published in the specified period from relevant top-ranking journals in the fields of education, management, and HRD. Sample journals were the Review of Educational Research (Scopus Q1 and Impact Factor 7.41), Organization Sciences (Scopus Q1 and Impact Factor 5.56), and Human Resources Development International (Scopus Q2 and Impact Factor 2.19). Third, the document analysis technique was used to review the selected articles.

In line with the inclusion and exclusion criteria, the search process consolidated more than 200 preliminary articles related to the term's employee competency, SDL, and $21^{\text {st }}$ century skills. At this stage, we found English and non-English literature, which we separated under inclusion and exclusion criteria that met our requirement for Asian countries. After retrieving the search results, they were filtered in table form. This allowed us to identify and remove 22 duplicate articles, resulting in 178 articles. Next, after reviewing the articles' titles and abstracts, we excluded 133 articles and included 
five more articles related to the topic. The search criteria were exported to the EndNote software, which aided the inclusion and exclusion process. Further details on the inclusion and exclusion criteria are described in the following sections.

Figure 3: Defining the Search Methods of the Systematic Literature Review

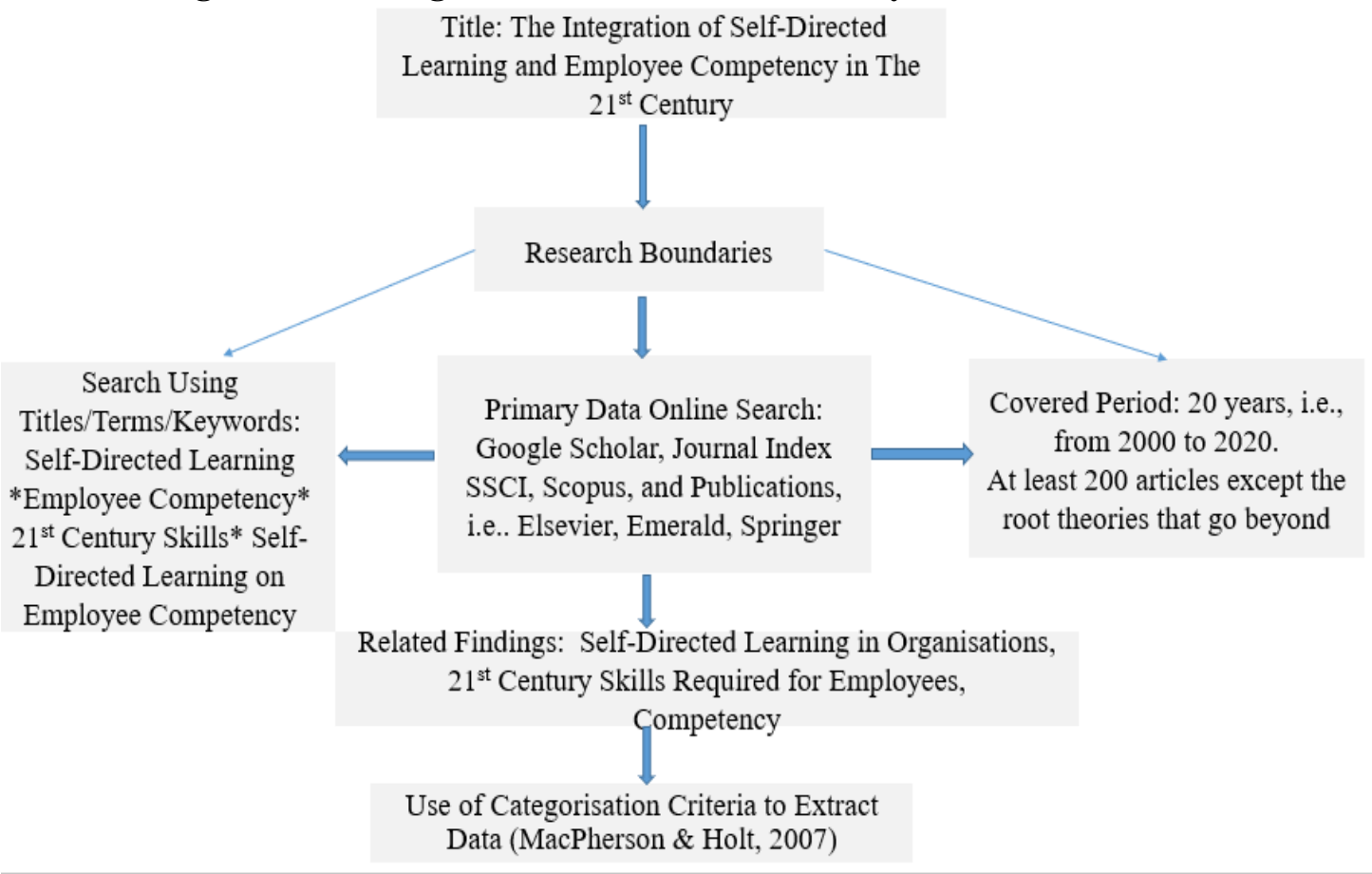

\section{Inclusion criteria}

Adopting inclusion criteria facilitates a standardised process to search relevant literature. In accordance with Snyder (2019), three criteria of inclusion were applied in this systematic review, which were 1) Peer-reviewed academic papers in the past 20 years; 2) The most relevant studies on SDL in relation to employee competency and $21^{\text {st }}$ century skills; and 3) Specification of the definition of employee competency, the integration of SDL, and employee competency. We captured all related studies that met these criteria for further analysis.

\section{Exclusion criteria}

Extensive evaluation of the articles was conducted to identify and eliminate irrelevant articles. First, we excluded studies not related to the management perspective, for instance, studies on SDL for teachers' ability in a purely educational context. Second, if an article examines the influence of learning and development on employee competency without an explicit reference to SDL, it was excluded. Lastly, we prioritised peer-reviewed academic journals; therefore, we excluded articles from nonacademic journals, conference papers, working papers, and corporate reports, in line with Rana et al. (2016). 


\section{Quality assessment}

The systematic literature review was performed using criteria outlined by the Database of Abstracts of Reviews of Effects (DARE), the Centre for Reviews and Dissemination (CRD), and York University (Snyder, 2019). There were four quality assessment (QA) questions as follows:

QA1. Were the review's inclusion and exclusion criteria described and appropriate? QA2. Was the literature search comprehensive of all relevant studies?

QA3. Did the reviewers evaluate the quality/validity of the included studies?

QA4. Were the basic data/studies adequately described?

Accordingly, as discussed in our inclusion criteria, we ensured the selected peer-review articles were published in top-ranking indexed journals. All selected articles were also relevant to the study areas and adequately fulfilled the above QA questions.

\section{Reviewing process}

Based on a final total of 50 identified studies, two clusters were constructed: SDL to enhance employee competency and employee competency for $21^{\text {st }}$ century skills. After the inclusion, exclusion, and QA criteria were evaluated, the extraction of relevant studies from the article search is depicted in Figure 4.

Figure 4: Procedure for article search

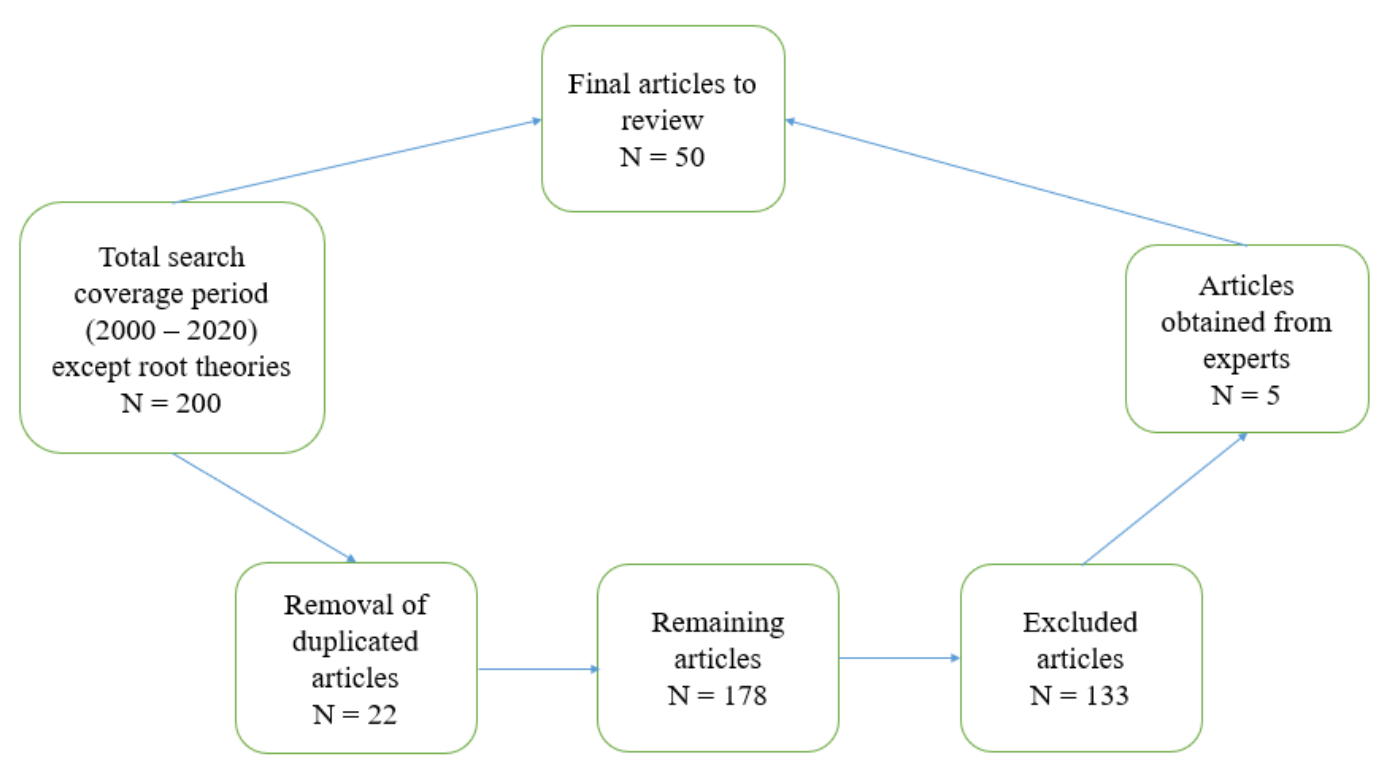

\section{Data Analysis and Synthesis}

This section presents the analysis of the articles after review. Two clusters were identified based on the keywords of the study topic. 


\section{Cluster 1 Self-directed learning (SDL) to enhance employee competency}

The concept of SDL was introduced by Knowles (1975), who defined the term as "an individual's initiative to plan and carry out learning by themselves". While Knowles described individuals in general, Marsick (2014) focused on the specific organisational context wherein SDL boosts employee competency. Likewise, Ellinger (2004) studied the role of HRD and leaders in developing employee competency through SDL in an organisation. To reach business competitiveness, Asian employers should motivate their employees and encourage them to improve their competency through self-directed learning (Yeo 2008). We ultimately identified 10 expert authors who have contributed to SDL studies following our criteria of publication year, recognised journals, and authorship (see Table 2).

Table 2: Studies on self-directed learning to enhance employee competency

\begin{tabular}{ccl}
\hline No. & Author/Year & \multicolumn{1}{c}{ Journal } \\
\hline 1 & Raveendran et al. (2021) & Organization Science \\
2 & Rana et al. (2016) & European Journal of Training and Development \\
3 & Boyer et al. (2013) & Journal of Marketing Education \\
4 & Waitoller and Artiles (2013) & Review of Educational Research \\
5 & Karakas and Manisaligil (2012) & European Journal of Training and Development \\
6 & Bentley and Kyvik (2012) & Higher Education \\
7 & Cho and Kwon (2005) & International Journal of Training and Development \\
8 & Ellinger (2004) & Advances in Developing Human Resources \\
9 & Merriam (2001) & New Directions for Adult and Continuing Education \\
10 & Knowles (1984) & Applying Modern Principles of Adult Learning \\
\hline
\end{tabular}

\section{Cluster 2 Employee competency for $21^{\text {st }}$ century skills}

In this cluster, the term 'employee' is defined specifically for the Asian context. The definition of competency by Skorkova (2016) provides the description of employee competency, while $21^{\text {st }}$ century skills is viewed from the perspective of the $4 \mathrm{Cs}$ as critical success factors for employees to secure and sustain their career progress in the workplace. With our inclusion criteria for year of publication and recognised journals, we finally synthesised 12 studies by expert authors on this topic, as per Table 3 .

Table 3: Studies on employee competency for $21^{\text {st }}$ century skills

\begin{tabular}{ccl}
\hline No. & Author/Year & \multicolumn{1}{c}{ Journal } \\
\hline 1 & Raveendran et al. (2021) & Organization Science \\
2 & Asia Pacific Economic Cooperation (2020) & Human Resources Development \\
3 & Mannayong and Haerul (2020) & Jurnal Ad'ministrare \\
4 & McGunagle and Zizka (2020) & Higher Education, Skills and Work- \\
& & Based Learning \\
5 & Potnuru and Sahoo (2016) & European Journal of Training and \\
& & Development \\
6 & Sarboini (2016) & Jurnal Ilmiah Peuradeun \\
7 & Skorková (2016) & Procedia - Social and Behavioral \\
& & Sciences \\
& Deng (2012) & International Journal of Management \\
& & Review
\end{tabular}




\begin{tabular}{ccl}
9 & Brockmann et al. (2009) & Journal of European Industrial Training \\
10 & Anderson (2006) & Journal of Business and Psychology \\
11 & Bybee and Fuchs (2006) & Journal of Research in Science \\
& & Teaching, \\
12 & Tan and Tan (2002) & Journal of Psychology \\
\hline
\end{tabular}

\section{Discussion and Conclusion}

With the holistic development of employees' knowledge and competency, it is significant for organisations to promote SDL among their employees. This highlights the need for a comprehensive review of existing relevant research in the workplace context. It is also imperative to identify the definitions and significance of employee competency, so that it can be incorporated in the adoption of $21^{\text {st }}$ century skills. To enhance employee competency, the promotion of SDL in the workplace needs to be investigated as well. This section presents the findings of this study on how SDL enhances employee competency, as well as its conclusion and implications for both scholars and practitioners.

Based on our findings, the definition of competency is positively related to personality traits, capabilities to achieve task completion, and performance that meets organisational expectations. Therefore, SDL can be conducted to enhance employee competency as follows:

1. Employees, as individuals, must be aware of themselves to practice independent learning and become self-directed learners.

2. Organisations should prioritise learning, particularly concerning crucial skills needed in the workplace, to achieve employee competency and company goals.

3. To comply with $21^{\text {st }}$ century skills requirements, organisations need to promote an SDL culture that achieves employee competency.

4. Although most previous literature has posited that SDL focuses on individual learning, Knowles (1984) argued that SDL could be fully enhanced by creating a climate of mutual learning, collaboration, and support in the workplace.

5. Merriam (2001) concurred that leaders must support the implementation of SDL strategies as tools to enhance employee competency in the workplace.

It has been widely acknowledged that knowledge creation and continuous learning at the individual, group, and organisational levels serve as critical sources for employee competency and organisational effectiveness (Karakas \& Manisaligil, 2012). In response to this, organisations are increasingly embracing the learning organisation concept; however, the cost-effectiveness of this concept remains an important consideration. Employees must thus be persistent in learning and developing their skills and competencies to accomplish organisational goals (Raemdonck et al., 2014).

Employees play a crucial role in the development of an organisation's requirements that are, of course, in line with $21^{\text {st }}$ century skills. As organisations attempt to establish and maintain a learning and development system to enhance employee competency. Employees are challenged to assume more responsibility for their learning to remain skillful, knowledgeable, and competitive qualification. In this regard, SDL is a critical tool that individuals can leverage to gain competencies. Thus, in recent years, HRD 
scholars have recognised the critical role of SDL in the workplace to enhance employee competency and develop learning organisations.

In conclusion, this paper suggests that learners should have a strong sense of unity and willingness to share knowledge for practical benefits. The followings are the practices to enhance SDL in the workplace:

- Employees' competency must be evaluated by superiors in cooperation with the human resources department so they can be aware of their skills and knowledge levels.

- HRD should build a shared vision to ensure communication among employees at all levels. Effective communication helps to enhance the learning process, including self-learning.

- HRD and leaders must encourage continuous learning and provide accessibility for employees to access knowledge and become self-directed learners.

- The creation of an organisational culture of collaboration, interaction, and teamwork in the organization level will facilitate learning from each other at the individual level (Lehner \& Sundby, 2017).

- Management should provide personalised coaching and instructions for each employee to develop necessary skills to achieve their personal goals and company expectations.

- SDL is learner-centered; therefore, the competency program must be developed with the cooperation of employees, the human resource department, and leaders (Ratana-Ubol \& Henschke, 2015).

This paper offers both scholarly and practical implications. First, our theoretical implication contributes to the SDL theory for employee competency enhancement in organisations for $21^{\text {st }}$ century skills. The SDL theory originated in the $1970 \mathrm{~s}$ and continues to be widely studied in the context of education and management, thereby proving its significance. We posit that this theory acts as a basis for employees to build their competency, especially in skills required in the $21^{\text {st }}$ century to improve work performance. Second, the findings provide data for human resource managers and designers of learning programmes to strategically enhance employee competency according to employee needs. That is, SDL allows them to better understand employees in planning development programmes to increase employee competency and career growth, given that Vithayaporn and Ashton (2019) found that employee career growth and organisational performance are positively related to training and development.

Lastly, we propose a conceptual model of SDL to enhance employee competency for $21^{\text {st }}$ century skills (see Figure 5). As mentioned, SDL is learner-centred, but the model recommends 'co' to reflect the interdependency between HR and employees. Employees become self-directed learners when they are self-motivated to learn, whereby HR is the facilitator that provides employee competency programmes for employees to do so. 
Figure 5: The HRD Programme Model

\section{Proposed Conceptual Model of Self-Directed Learning to Enhance Employee Competency Through Programme Planning}

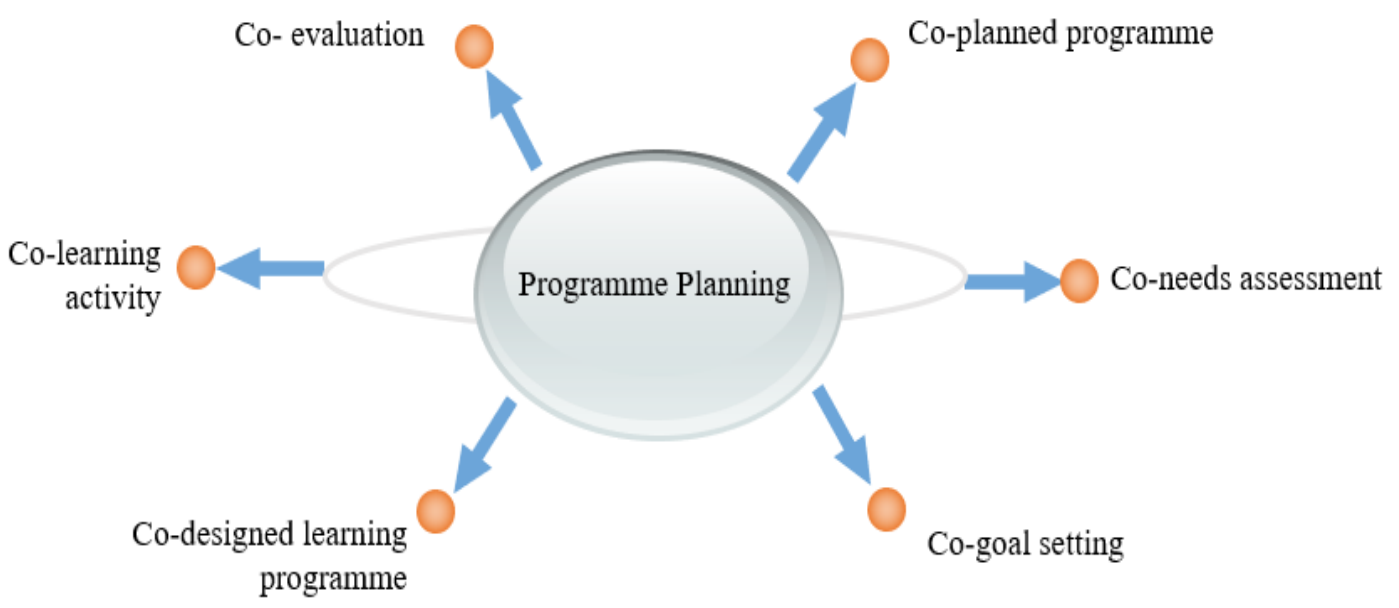

\section{Limitations and Recommendations}

First, based on our findings, the limitation of the study demonstrate that few scholars have integrated the idea of SDL with employee competency. This line of research is still emerging, evidenced by the limited empirical study on SDL in the workplace context. It is important to address this gap in the literature to investigate the association between employee competency and SDL in the $21^{\text {st }}$ century. Due to the competitive working environment, expecting full instructions from one's manager or waiting for guidance is no longer acceptable. New graduates should improve themselves with SDL to be better equipped in their workplace and to be able to contribute to the management with useful insights when required. Second, our search was limited to academic journals, books written by academics, and news articles. Future studies are recommended to examine the relationship between SDL and employee competency in the workplace context by expanding the search to practitioners' books, magazines, and trade articles. This is vital as practitioners' insights are generally up-to-date and relevant to the industry's current issues.

\section{Practical Implications for Asian Business}

This paper offers implications for practitioners in Asia. The Asia-Pacific Economic Cooperation (APEC) promotes the importance of developing $21^{\text {st }}$ century skills for increased employee competency and consequently, sustainable economic growth in the region. To achieve the region's economic capacity, human capital with the necessary ability through education and skills enhancement program plays a contributive role. In its mission to share knowledge and strengthen employees' competency in the region, APEC has implemented the Human Resources Development Working Group 
(HRDWG) since 1990 (APEC, 2020). The HRDWG has worked under APCE's guidelines to develop the region's capacity competitiveness and $21^{\text {st }}$ century skills. This paper offers some essential skills for the $21^{\text {st }}$ century workplace to support APEC's mission and to help HRDWG the implementation of employee competency program.

First, this paper underlines the importance of competency enhancement based on the $21^{\text {st }}$ century skills required for Asian countries to compete globally. This can be done by promoting SDL in the workplace to enhance employee competency. SDL is usually developed by adult learners themselves outside the classroom and is not something that is taught in higher education. Nevertheless, SDL is a critical skill that should be developed among workers to ensure they have the key skills needed for the $21^{\text {st }}$ century.

Second, the study highlights the concept of SDL that enables independent adult learners to increase their capability to perform in the workplace, which eventually enhances organisational effectiveness. Since Asian workers are more passive, HRD practitioners or management can inculcate SDL by providing a conducive working environment. In particular, though structured learning systems are significant, workers should also be offered the opportunity to steer their learning with more self-control and selfmanagement. This can be done by providing workers more flexibility to improve their learning, thereby making them feel driven and inspired. Employers also should consider rewarding employees who exhibit SDL as a sign of encouragement.

Third, our study gives insight into the importance of human resource practices, such as training and development and performance appraisal, in enhancing employee competency. HRD has become closely aligned with organisational strategies. Moreover, learning, a primary key to developing employee competency, is a crucial part of organisational culture. By cultivating an SDL culture among employees through all kinds of learning, we suggest that employees can become self-directed learners in the organisation. Likewise, Goncalo and Staw (2006) pointed out that Asian culture is influenced by collectivism, harmony, and a group orientation; hence, building teambased learning through leaders, managers, and supervisors may engage employees in active learning and self-development skills through SDL. In addition, on-the-job learning facilities allow companies to pass the obligation of learning to workers and make it easier for them to learn, contextualise, and apply their learning. Particularly, amid the Covid-19 pandemic, organisational revenue has been severely impacted, effectively eliminating training and development budgets. Therefore, SDL is the best and most cost-effective solution to employees' learning so they can enhance their competency in $21^{\text {st }}$ century skills.

\section{References}

Anderson, J. R., (2006), "Managing employees in the service sector: A literature review and conceptual development”, Journal of Business and Psychology, vol. 20, no. 4, pp. 501523.

Asia Pacific Economic Cooperation., (2020), Human resources development. Retrieved from https://www.apec.org/Groups/SOM-Steering-Committee-on-Economic-and-

Technical-Cooperation/Working-Groups/Human-Resources-Development

Bentley, P. J., \& Kyvik, S., (2012), "Academic work from a comparative perspective: a survey of faculty working time across 13 countries", Higher Education, vol. 63, no. 4, pp. 529-547. 
Boyer, S.L., Edmondson, D.R., Artis, A.B. and Fleming, D., (2013), "Self-directed learning a tool for lifelong learning", Journal of Marketing Education, vol. 36, no. 1, pp. 20-32.

Brockmann, M., Clarke, L., \& Winch, C., (2009), "Competence and competency in the EQF and in European VET systems", Journal of European Industrial Training, vol. 33, no. 8/9, pp.787-799.

Bybee, R. W., \& Fuchs, B., (2006), "Preparing the $21^{\text {st }}$-century workforce: A new reform in science and technology education", Journal of Research in Science Teaching, vol. 43, no. 4, pp. 349-352.

Cho, D. and Kwon, D.B., (2005), "Self-directed learning readiness as an antecedent of organizational commitment: a Korean study", International Journal of Training and Development, vol. 9 No. 2, pp. 140-152.

Deng, P. (2012), "The internationalization of Chinese firms: a critical review and future research", International Journal of Management Reviews, vol. 14, no. 4, pp. 408-427.

Dutta, S., Geiger, T., \& Lanvin, B., (2015), "The global information technology report 2015." In World Economic Forum, vol. 1, no. 1, pp. 80-85.

EC (European Commission)., (2018), "European Pillar of Social Rights", Retrieved from https://ec.europa.eu/commission/sites/beta-political/files/social-summit-europeanpillarsocial-

Edwards, M. R., (2010), "An integrative review of employer branding and OB theory", Personnel Review, vol. 39, no. 1, pp. 5-23.

Ellinger, A. D., (2004), "The concept of self-directed learning and its implications for human resource development", Advances in Developing Human Resources, vol. 6, no. 2, pp.158-177.

Ernst \& Young., (2013), "Six Global Trends Shaping the Business World: Emerging Markets Increase their Global Power", Retrieved from http://www.ey.com/GL/en/Issues/Business-environment/ Six-global-trends-shapingthe-business-world--- Emerging-markets-increase-their-global-power.

Fagan, C., Norman, H., Smith, M., \& Menéndez, M. C. G., (2014), "In Search of Good Quality Part-Time Employment", International Labour Office, Retrieved from https://www.ilo.org/wcmsp5/groups/public/---ed_protect/---protrav/--travail/documents/publication/wcms_237781.pdf

Felipe, J., Sawada, Y., Estrada, G., \& Bajaro, D. F., (2020), "Why do Filipino's desire to work more hours?", Asian-Pacific Economic Literature, vol. 34, no. 2, pp. 106-132.

Goncalo, J. and Staw, B., (2006), "Individualism - collectivism and group creativity", Organizational Behavior and Human Decision Processes, vol. 100, no. 1, pp. 96-109.

Ha, T. S., (2015), "Learning stories from IT workers - Development of professional expertise", Studies in Continuing Education, vol. 37, no. 1, pp. 79-98.

International Labour Organization, (2010), "Guidelines for Recognizing the Skills of Returning

Migrant Workers", Retrieved from http://apskills.ilo.org/resources/guidelines-for-recognizingthe-skills-ofreturning-migrant-workers/at_download/file2

International Monetary Fund (IMF), 2010, "World Economic Outlook Database", Retrieved from http://www.imf.org/external/ pubs/ft/weo/2010/02/weodata/index.aspx

Jaques, E., (2017), Requisite organization: A total system for effective managerial organization and managerial leadership for the 21st century, Routledge, Arlington.

Joynes, C., Rossignoli, S., \& Fenyiwa Amonoo-Kuofi, E., (2019), $21^{\text {st }}$ century skills: Evidence of issues in definition, demand, and delivery for development contexts (K4D helpdesk report), Institute of Development Studies, Brighton.

Karakas, F. and Manisaligil, A., (2012), "Reorienting self-directed learning for the creative digital era", European Journal of Training and Development, vol. 36, no. 7, pp. 712731.

Klemp Jr, George O., (1980), "The Assessment of Occupational Competence. Final Report: Introduction and Overview", Retrieved from http://eric.ed.gov/?id=ED192164

Knowles, M., (1975), Self-directed learning: A guide for learners and teachers, Follett Publishing Company, Chicago. 
Knowles, M.S., (1984), Andragogy in Action: Applying Modern Principles of Adult Learning, Jossey-Bass, San Francisco.

Kunzmann, C. and Schmidt, A., (2006), "Ontology-based competence management for healthcare training planning: a case study", I-know international conference on knowledge management, vol. 6, pp. 143-150.

Lee, Y.T., (2010), "Exploring high performer's required competencies", Expert Systems with Applications, vol. 37, no. 1, pp. 434-439.

Lehner, F., 2018. IT capabilities for SMEs: An analysis at the organisational level. In The Impact of Digitalization in the Workplace, Springer, Cham, pp. 125-139.

Lindeman, E., (1926), The meaning of adult education, New Republic Inc, New York.

Macpherson, A. and Holt, R., (2007), "Knowledge, learning and small firm growth: a systematic review of the evidence", Research Policy, vol. 36, no. 2, pp. 172-192.

Mannayong, J., \& Haerul, H., (2020), "Analysis of employee competency development at the corporate headquarters of Makassar Raya Makassar City Market." Jurnal Ad'ministrare, vol. 6, no. 2, pp.137-144.

Manpower Research \& Statistics Department, MOM, (2020), "Labour Market Survey", Retrieved from https://stats.mom.gov.sg/Pages/Hours-Worked-Summary-Table.aspx

Marsick, V.J., Watkins, K.E., Callahan, M.W. and Volpe, M., (2008), Informal and incidental learning in the workplace. In Handbook of research on adult learning and development, Routledge, New York, pp. 592-622.

McDonald, S. D., (2017), "Enhanced critical thinking skills through problem-solving games in secondary schools", Interdisciplinary Journal of E-Learning \& Learning Objects, vol. 13.

McGunagle, D., \& Zizka, L., (2020), "Employability skills for 21st-century STEM students: the employers' perspective", Higher Education, Skills and Work-Based Learning, vol 10, no 3, pp 591-606.

Merriam, S.B., (2001), "Andragogy and self-directed learning: pillars of adult learning theory", New Directions for Adult and Continuing Education, no. 89, pp. 3-13.

Northouse, Peter., (2004), Leadership theory and practice, Sage Publications, Thousand Oaks.

Office of the National Economic and Social Development Board., (2016), "Thailand 20-year National Strategic Plan", Retrieved from http://nscr.nesdb.go.th/wpcontent/uploads/2019/10/National-Strategy-Eng-Final-25-OCT-2019.pdf

Parry, S.R., (1996), The quest for competence, Training Magazine, pp. 48-56.

Pereira, J. P., Natalya, E., \& Slesarenko, I., (2020), "The analysis of competency model for a performance appraisal system in the management of food service industry", International Conference on Information Technology and Systems, pp. 162-171.

Pinyosinwat, P., \& Preudhikulpradab, S. V., (2018), "An initial analysis of leadership competencies for organization development intervention: a case study of educational QA agency", ABAC ODI Journal Vision. Action. Outcome, vol. 5, no. 2, pp. 1.

Potnuru, R. K. G., \& Sahoo, C. K., (2016), "HRD interventions, employee competencies and organizational effectiveness: An empirical study", European Journal of Training and Development, vol. 40, no. 5, pp. 345-365.

Raemdonck, I., Gijbels, D. and van Groen, W., (2014), "The influence of job characteristics and self-directed learning orientation on workplace learning", International Journal of Training and Development, vol. 18, no. 3, pp. 188-203.

Rana, S., Ardichvili, A. and Polesello, D., (2016), "Promoting self-directed learning in a learning organization: tools and practices", European Journal of Training and Development, vol. 40, no. 7, pp. 470-489.

Raveendran, M., Puranam, P., \& Warglien, M, (2021), "Division of labor through selfselection", Organization Science, pp. 1-25.

Ratana-Ubol, A., \& Henschke, J. A., (2015), "Cultural learning processes through local wisdom: A case study on adult and lifelong learning in Thailand", International Journal of Adult Vocational Education and Technology, vol 6, no 2, pp. 41-60. 
Sarboini, S., (2016), "Performance of Employees and Impact on Promotion of Position", Jurnal Ilmiah Peuradeun, no. 1, pp.103-114.

Sanghi, S., (2007), The handbook of competency mapping: Understanding, designing and implementing competency models in organizations, Sage Publications, New Delhi.

Scott, C. L., (2015), "The Futures of Learning 2: What Kind of Learning for the 21st Century? (ERF Working Paper No. 14)", UNESCO, Retrieved from https://tinyurl.com/y8a4ry4h.

Skorková, Z., (2016), "Competency models in the public sector", Procedia - Social and Behavioral Sciences, vol. 230, pp. 226-234.

Snyder, H., (2019), "Literature review as a research methodology: An overview and guidelines", Journal of Business Research, vol. 104, pp. 333-339.

Spies, T. G., \& Xu, Y., (2018), "Scaffolded Academic Conversations: Access to 21st-Century Collaboration and Communication Skills", Intervention in School and Clinic, vol. 54, no. 1 , pp. 22-30.

Tan, H.-H., \& Tan, C.P., (2002), “Temporary employees in Singapore: What drives them?", The Journal of Psychology, vol. 136, no. 1, pp. 83-102.

Uijtdewilligen, L., Yin, J. D.-C., Van Der Ploeg, H. P., \& Müller-Riemenschneider, F., (2017), "Correlates of occupational, leisure and total sitting time in working adults: results from the Singapore multi-ethnic cohort", International Journal of Behavioral Nutrition and Physical Activity, vol. 14, no. 1.

van Laar, E., van Deursen, A. J., van Dijk, J. A., \& de Haan, J., (2020), "Determinants of 21stcentury skills and 21st-century digital skills for workers: A systematic literature review", Sage Open, vol. 10, no. 1.

Vithayaporn, S., \& Ashton, A. S., (2019), "Employee engagement and innovative work behavior: A case study of Thai airways international", ABAC ODI Journal Vision. Action. Outcome, vol. 6, no. 2, pp. 45.

Waitoller, F. R., \& Artiles, A. J., (2013), "A decade of professional development research for inclusive education: A critical review and notes for a research program", Review of Educational Research, vol. 83, no. 3, pp. 319-356.

Widyahening, I. S., Thuraiappah, D. M., Han, T. M., \& Vidiawati, D., (2014), "Indonesian primary care physicians' profile in 2011: Did practicing hours and conversion program for family medicine differentiate their services and continuing medical education activities?", Asia Pacific Family Medicine, vol. 13, no. 1.

World Economic Forum., (2009), "The Global Competitiveness Report 2009-2010. Geneva: World Economic Forum", Retrieved from http://www3.weforum.org/docs/WEF_GlobalCompetitivenessReport_2009-10.pdf

Yeo, R.K., (2008), "How does learning (not) take place in problem-based learning activities in workplace contexts", Human Resource Development International, vol. 11, no. 3, pp. $317-330$. 